\title{
Effect of Level Soil Bund and Fayna Juu on Soil Physico-chemical Properties, and Farmers Adoption Towards the Practice at Dale Wabera District, Western Ethiopia
}

\author{
Sirna Gadisa ${ }^{1}$, , Leta Hailu ${ }^{2}$ \\ ${ }^{1}$ Dale Wabera District Agricultural and Rural Development Office, Kake, Ethiopia \\ ${ }^{2}$ Jimma Agricultural Research Center, Jimma, Ethiopia
}

Email address:

sirnagadisa2017@gmail.com (S. Gadisa)

${ }^{*}$ Corresponding author

To cite this article:

Sirna Gadisa, Leta Hailu. Effect of Level Soil Bund and Fayna Juu on Soil Physico-chemical Properties, and Farmers Adoption Towards the Practice at Dale Wabera District, Western Ethiopia. American Journal of Environmental Protection.

Vol. 9, No. 5, 2020, pp. 102-115. doi: 10.11648/j.ajep.20200905.12

Received: August 14, 2020; Accepted: October 28, 2020; Published: October 30, 2020

\begin{abstract}
The objective of this study was to evaluate the effect of physical soil and water conservation (SWC) structures and slope gradients on soil properties and to identify factors affecting farmer's adoption of the SWC practices. Cropland treated with level soil bund, fanya juu, and adjacent cropland without conservation structures were considered along the three slope gradients. A total of 27 soil samples were collected from the top $20 \mathrm{~cm}$ soil depth in ' $\mathrm{X}$ ' design square plot with a length of $10 \mathrm{~m} \times 10 \mathrm{~m}$ and replicated three times. A total of 120 households $(\mathrm{HH})$ were randomly selected among which $48.3 \%$ were adopters and $51.7 \%$ were non-adopters of SWC structures. The collected soil samples were analyzed following standard laboratory procedures and a total of 10 variables were fitted in the logistic regression model. The result of the analysis revealed that sand fraction (\%), SOC (\%), TN (\%), CEC (meq/100gm), and $\mathrm{pH}\left(\mathrm{H}_{2} \mathrm{O}\right)$ were showed significant $(\mathrm{P} \leq 0.05)$ differences between cropland treated with conservation structures and control plots; however, available $\mathrm{P}(\mathrm{ppm})$ did not show significant $(\mathrm{P} \leq 0.05)$ variation. With regard to slope gradient, soil textural fractions sand $(\%)$, Silt $(\%)$ and Clay (\%), and CEC (meq/100gm) were showed significant difference $(\mathrm{P} \leq 0.05)$. While BD $\left(\mathrm{g} \mathrm{cm}^{-3}\right)$, SMC $(\%)$, SOC $(\%)$, TN $(\%)$, and available $\mathrm{P}$ (ppm) did not significantly differ along the slope. The result of the model also showed that the explanatory variables; age, education level, family size, landholding, farm experience, availability of labor shortage, and extension service were significantly affected the adoption of SWC practices by the farmers. On the other hand; sex, marital status, and livestock holding were not significantly affected farmers' adoption of SWC practice. Therefore, scaling up of the soil bund for the area is necessary and building capacity, providing training and experience-sharing through field days for farmers is essential. Moreover, further investigation is encouraged on the integrated effect of physical and biological SWC practice and its socioeconomic aspects for a better understanding of the effect of sustainable use of the land.
\end{abstract}

Keywords: Level Fanya Juu, Level Soil Bund, Slope Gradient, Soil Physicochemical Properties

\section{Introduction}

Soil erosion is a serious problem in Ethiopia [1]. Deforestation, population growth, overgrazing, and the use of marginal lands, topography, soil type, and the intensification of agriculture production are some of the causes of soil erosion [2]. Various studies conducted revealed that annual soil loss shows spatial and temporal variations, even if the average annual soil loss of the country estimated to be 12 tons $\mathrm{ha}^{-1} \mathrm{yr}^{-1}$ [3]. For instance, in the Koga catchment northwestern Ethiopia, annual soil loss of $25 \mathrm{mg} \mathrm{ha}^{-1}$ year ${ }^{1}$ was reported [4], $91.6 \mathrm{mg} \mathrm{ha}^{-1}$ year $^{-1}$ in Fincha watershed, western Ethiopia [5], and $23.4 \mathrm{mg} \mathrm{ha}^{-1}$ year $^{-1}$ in Modjo watershed central Ethiopia [6]. Several studies confirmed that 
land degradation due to soil erosion and associated soil nutrient depletion, are the major cause of the decline of agricultural production in Ethiopia [7]. Soil erosion leads to soil organic carbon loss along with the transported soil sediment [8]. The loss of soil organic carbon results in the decreased crop production potential of the soil [9].

In Ethiopia, the soil erosion problem gain focus following the 1970s famine occurred in the country [10]. Farmers were mobilized through their peasant associations and huge hectares of the land were treated by different soil and water conservation practices through a program food for work [11]. The principal aims of the interventions were to reduce soil erosion, restore soil fertility, rehabilitate degraded soils, improve microclimate, and enhance agricultural productivity [12]. Recently, the Ethiopian government launched a land restoration program through community participation to increase production and productivity by improving natural resource management [13]. Likewise, in the Dale wabera district, various soil and water conservation measures were implemented as a part of the land restoration campaign program through community participation and NGOs since 2011.

As reported by many scholars, physical soil and water conservation practices had shown a significant effect on soil physical and chemical properties, on conserved cropland as compared to untreated cropland [14]. Effectiveness of soil and water conservation is site specific, which apparently depends on complex and interacting site specific factors such as the local geology, geomorphology, topography, and climate and land use history $[15,16]$. Furthermore, the most important reason for limited use of SWC technologies is farmers' low adoption behavior. According to [17], SWC measures fully adopted only when the execution is sustained and fully integrated into the household's farming system. Previous studies show that various personal, economic, social, institutional, and biophysical as well as political attributes have influential roles in farmers' decisions about the adoption of SWC practices in different areas of Ethiopia. However, these attributes and effects of structural soil and water conservation are not yet studied in Dale Wabera districts of western Ethiopia. Therefore, the intention of the study was to investigate the effect of implemented level soil bund and fayna juu on selected soil physicochemical properties and factors influence the adoption of soil and water conservation practice of the farmers of Dale Wabera district, western Ethiopia.

\section{Materials and Methods}

\subsection{Description of the Study Area}

Location: The study was conducted in the Dale Wabera district, Kelem Wolega zone, Oromia Regional State of Ethiopia. It is located at about $585 \mathrm{~km}$ in the western direction from Addis Ababa, the capital city of Ethiopia. Geographically, it is between latitude $08^{\circ} 40^{\prime} 00^{\prime \prime}$ $09^{\circ} 10^{\prime} 00^{\prime \prime} \mathrm{N}$ and longitude of $035^{\circ} 00^{\prime} 00^{\prime \prime}-035^{\circ} 10^{\prime} 00^{\prime \prime} \mathrm{E}$ [Figure 1].

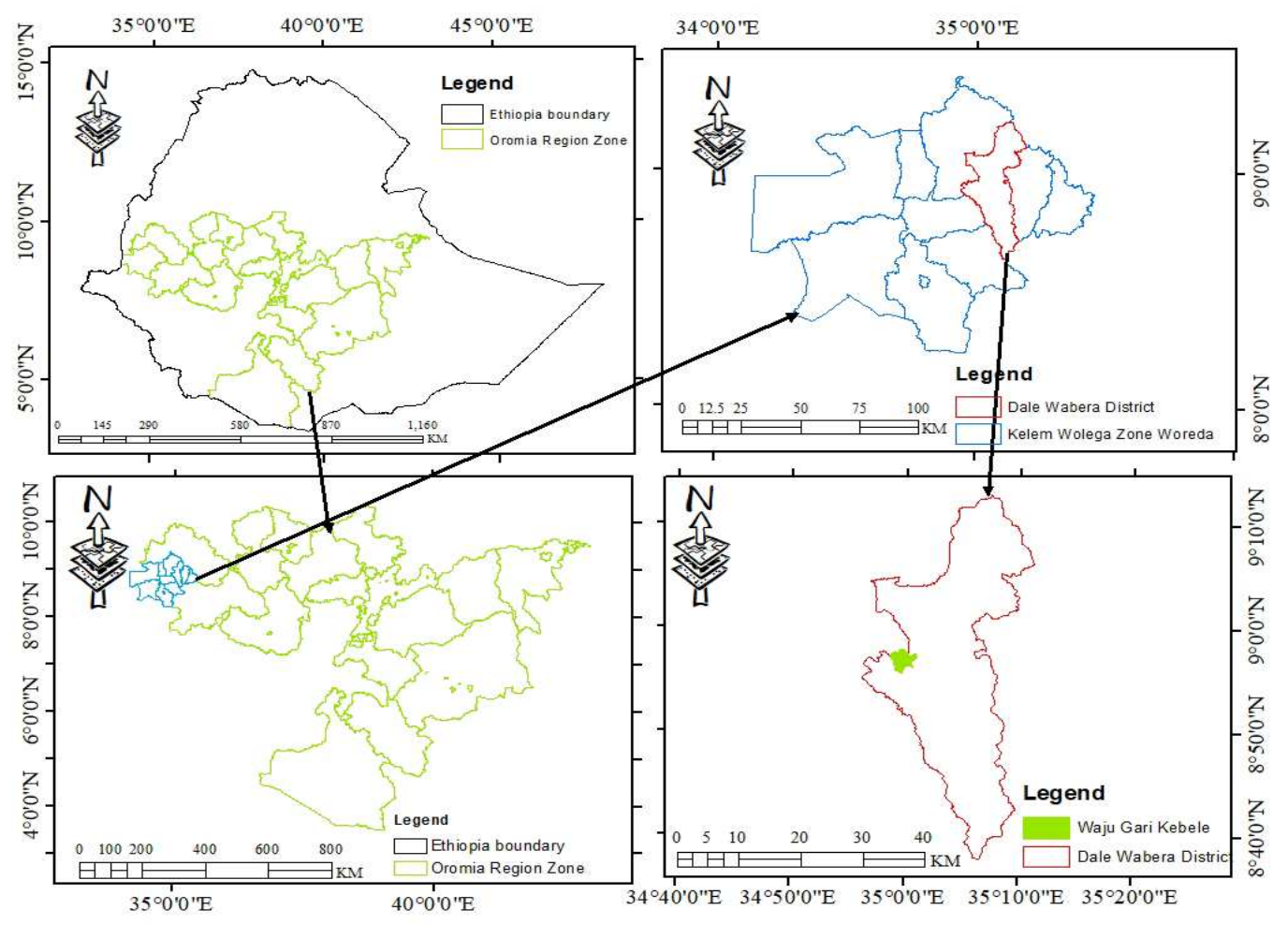

Figure 1. Map of Dale Wabera district, Kelem Wolega Zone, Western of Ethiopia.

Population: According to the 2007 national census report a total population of the district was 105,708 , of whom 53,008 were men and 52,700 were women; 14,105 or $13.51 \%$ of its population were urban dwellers. The majority of the residents 
were Protestants, followed by Islam and Orthodox Christianity [18].

Agro-ecology and soil: The mean annual rainfall of the study area is $1500 \mathrm{~mm}$, ranges from $1200 \mathrm{~mm}$ to $1800 \mathrm{~mm}$ and temperature varies from $21^{\circ} \mathrm{C}$ to $29^{\circ} \mathrm{C}$ with an average daily temperature of $25^{\circ} \mathrm{C}$. The altitude of the district is lying between 1200 to 2200 m.a.s.1 with an average elevation of 1700 m.a.s.1 [19]. The major soil of the district is Nitisols $(80 \%)$ and vertisols $(17 \%)$ and others $(3 \%)$ [20].

Economic activity: The economic base of the district is agriculture and the sector is rain-fed and characterized by low productivity. The agro-climatic condition is favorable for growing diversified crops, including annual and perennial crops. Barley (Hordeum vulgare), Teff (Eragrostisteff), Sorghum, Maize (Zea mays), and finger millet are major cereals grown by the farmers. Fruits and vegetables are grown by some farmers for food and income. Irrigated agriculture using streams and springs is limited and practiced by a few farmers to grow vegetables and maize for household consumption and for the local market. Livestock is an integral part of the farming system of the district. The more source of power for land cultivation is oxen and equines for transportation. The major animals reared in the area are cattle, small ruminants, and equines. In the district, livestock production is constrained by a shortage of feed and poor genetic potential of local breeds [20].

\subsection{Experimental Design and Sampling Procedures}

The study area was purposively selected from the 11 districts of Kelem Wolega zone and 22 Kebeles of the Dale wabera district as Waju Gari kebele provides us an opportunity to find out different SWC practices and experience to the problem of soil erosion and low adoption of physical soil and water conservation practices. Waju Gari kebele is included under the project sites of an NGO known as Menschen fiir menschen.

Soil sample collection: A reconnaissance survey was conducted to select representative sample plots within the selected Kebele. Soil samples were collected farmland treated with Level soil bund and Fayna juu of seven years aged and adjacent farmland without conservation measures as a control. Samples were taken between the consecutive conservation structures and adjacent cropland without conservation. Soil samples were collected from the top 0-20 $\mathrm{cm}$ depth at four corners and center of a plot of $10 \mathrm{~m} \times 10 \mathrm{~m}$ size using " $\mathrm{X}$ " sampling design [21], with sharp-edged and closed, circular auger pushed manually down the soil profile from the three slope classes namely, gentle sloping (5-10\%), medium sloping (10-15\%) and steep sloping (15-30) according to FAO soil description [22]. A total of 27 composite soil samples ( 3 treatments $* 3$ slope gradients $* 3$ replications) were collected by using randomized completed block design (RCBD) for soil analysis. For BD determination after clearing the top surface crop residues and others, undisturbed soil samples were taken from the center of each sampling plot with a core sampler. Finally, the collected soil samples were transported to the Nekemte soil research center and Jimma University College of Agriculture and Veterinary Medicine (JUCAVM) soil laboratory for analysis of selected soil physicochemical properties.

Laboratory analysis: Samples were air-dried at room temperature, homogenized, and passed through a $2 \mathrm{~mm}$ sieve. Soil bulk density was determined by the soil core method which is the ratio of oven-dried mass of soil to core volume [23] and soil texture fractions (sand, silt, and clay contents) were obtained by sieving and decantation procedures according to [24]. Soil organic carbon (SOC) was determined by the wet combustion procedure of the Walkley and Black method [25]. Soil TN was measured after sulfuric digestion following the Kjeldahl distillation process [26]. Soil $\mathrm{pH}$ was determined by using the glass electrode and hydrometer method as suggested by [27]. Available phosphorus was determined using the Bray II method [28]. Cation exchange capacity (CEC) of the soils was determined by the ammonium acetate $(\mathrm{pH} 7)$ method using the percolation tube procedure [27].

Socioeconomic data collection: Structured questionnaire, direct field observation, and focus group discussion were employed to collect socioeconomic data across a transect line of the study area. Data enumerators were trained on the techniques of data collection. After they were made aware of the objective of the study and the content of the questionnaire, a pre-test had been conducted under the supervision of the researcher. Data were collected under the continuous supervision of the researcher. The key informant interview was used to collect in-depth information about soil and water conservation practice of the district. The information gathered via key informant interviews was used to complement the data collected from a household survey via structured questionnaires and other sources. Accordingly, 8 experts 4 from the woreda office of agriculture and natural resource and 4 from Dale Wabera integrated rural development project (Menschen fiir Menschen) were selected and interviewed in-depth about the SWC practice of the district. Direct field observation was conducted through transect walks within the kebele to obtain information about the physical background of the area, conditions of soil erosion, condition of the present soil and water conservation practices status.

Farmer group discussion (FGD) was held with 10 women and men to assess farmers' adoption of SWC practices. These farmers were selected based on their adoption level of soil and water conservation on their farmlands. A checklist was prepared to guide the open ended discussion with the identified FGD members. The data collected from the FGD were qualitative and general which reflects the causes of soil erosion, consequences of soil erosion, and practices of soil and water conservation on their farmland. A questionnaire survey was applied to collect primary data from sample households using a structured questionnaire. An explanation those included in the household $(\mathrm{HH})$ survey was demographic and socioeconomic characteristics of households; farmers' adoption of different SWC practices and its impacts on determining soil properties. Waju Gari has a total of 314 
households [20]. From this total sample size for household interview was determined according to [29].

$$
\begin{aligned}
& \mathrm{n}_{\mathrm{o}}=\frac{\mathrm{z}^{2} * \mathrm{pq}}{\mathrm{e}^{2}} \\
& \mathrm{n}_{1}=\frac{\mathrm{n}_{\mathrm{o}}}{1+\left(\frac{\mathrm{n}_{\mathrm{o}}}{\mathrm{N}}\right)}
\end{aligned}
$$

Where:

$\mathrm{n}_{0}=$ desired sample size according to [29] when population greater than 10,000

$\mathrm{n}_{1}=$ Finite population correction factors [29] population less than 10,000

$\mathrm{Z}=$ Standard normal deviation (1.96 for $95 \%$ confidence level)

$\mathrm{P}=0.15$ (population variability i.e. $15 \%$ )

$\mathrm{q}=$ is 1 - Pi.e. $(0.85)$

$\mathrm{N}=$ is total number of population

$\mathrm{e}=\mathrm{is}$ degree of accuracy desired (0.05);

Thus,

$$
\begin{gathered}
n_{o=} \frac{1.96^{2} * 0.85 * 0.15}{0.05^{2}} \\
\mathrm{n} 1=\frac{195.9}{1+\frac{195.9}{314}}=120
\end{gathered}
$$

Accordingly, 120 sample households were a randomly selected from the three zones of the kebele using random number sampling technique and they were interviewed.

Data analysis: Soil data were subjected to analysis of variance using the general linear model (GLM) procedure of the statistical analysis system (SAS, version 9.3). The GLM model was used because it can generalize multiple linear regressions for more than one dependent variable. The model is given as:

$$
y i j=\mu+\alpha i+\beta j+(\alpha \beta) i j+£ i j
$$

Where; $y i j=$ dependent variables (soil properties) $\mu=$ sample mean, $\alpha i=$ effect of slope $\beta j=$ effects of treatments $(\alpha \beta) i j=$ interaction effect of slope and treatments. $£ i j=$ random error

The data collected from the HH survey were coded, edited, and entered into Microsoft Excel and imported into the static package for the Social Sciences (SPSS) version 20 software, where descriptive statistics, mean, standard deviations, and binary logistic regressions were conducted. The data which were obtained from the interview, focus group discussion and field observation was analyzed qualitatively to supplement the survey questionnaire.

\section{Results and Discussion}

\subsection{Effect of Level Soil Bund and Fanya Juu on Selected Soil Physical Properties}

Soil particle fractions: Soil particle fraction (\%) of sand content was showed significant difference $(p \leq 0.05)$ between conserved and non-conserved farmlands. The highest mean was observed under farmland treated with fayna juu. Though, silt and clay content did not show significant difference between conserved and non-conserved farmlands [Table 1]. The variation in sand content might be due to inherent soil property derived from the parent material since soil texture is not affected by conservation measures within such a short period of time. The higher mean sand content at the fanya juu apparently due to deposition of eroded soil was formed at the upper side of the ditch and the graveled materials left behind which might increase the sand contents on the upper side of $f$ anya juu structures. Regarding slope gradients, soil textural fraction $(\%)$ was exhibited significant $(\mathrm{p} \leq 0.05)$ difference under slope gradients. Sand content and clay content (\%) was showed a significant difference under gentle slope than a middle and steep slope, while silt content (\%) was demonstrated a significant $(p \leq 0.05)$ difference between gentle and steep slope [Table 2]. This result was in line with the finding of [30] who reported soil textural fractions sand, silt and clay (\%) showed significant difference with regard to slope gradient on the study conducted at Gondar zuria district. Looking at the particle size distribution, it was observed that the clay content showed an increasing trend as the slope gradient lowers while sand content conversely showed a decreasing trend down the slope gradient. The variation may be due to transportation and translocation of fine particles through selectively transported and/or leached fine fractions leaving behind the coarser fraction. Similar findings are reported by [31]; [32], that the highest silt content was observed at steep slopes. This result also confirms the findings of [30], who reported that on the steep slope, the most noticeable changes were a decrease in clay and a corresponding increase in sand and silt fractions as the slope gradient increases.

Bulk density $\left(\mathrm{g} \mathrm{cm}^{-3}\right)$ : The result of the analysis was presented that bulk density did not show significant variation between treatments and slope gradient. However, the higher means were observed under the control plot and middle slope gradient [Tables 1\&2]. This was clearly due to the removal of fertile topsoil and organic matter on non-conserved plot and steep slope through the erosion process. The result was in agreement with the finding of [33], who reported no significant variation was observed in bulk density between conserved and non-conserved farmlands and slope.

Soil moisture (\%): Even though there was no significant difference between treatments and slope gradient regarding the view of moisture contents, the higher mean value (20.53\%) was recorded for gentle slope and for soil bund structure (20.44), respectively. This might be due to the high quantity of clay soil and organic matter content at the gentle slope which has major implications to retain water in the soil. Clay soils are fine-textured and have a large surface area which allows as oil to hold more water. The results were supported by [34], who found that the areas near the bottom of the slope had higher soil-moisture content than areas near the top of the slope. Nevertheless, the result was in contrast with the findings of [35], who reported the highest moisture content for the middle slope rather than a gentle slope. 
Table 1. Mean value of soil physical properties as influenced by level soil bund and fanya juu.

\begin{tabular}{llllll}
\hline \multirow{2}{*}{ Treatments } & \multicolumn{5}{c}{ Parameters } \\
\cline { 2 - 6 } & Sand (\%) & Clay (\%) & Silt (\%) & BD (g/cm $\left.\mathbf{c m}^{\mathbf{3}}\right)$ & MC $(\%)$ \\
\hline Control & $35.22^{\mathrm{ab}}$ & $39.33^{\mathrm{a}}$ & $25.44^{\mathrm{a}}$ & $1.26^{\mathrm{a}}$ & $19.85^{\mathrm{a}}$ \\
Soil bund & $31.22^{\mathrm{b}}$ & $41.77^{\mathrm{a}}$ & $27.00^{\mathrm{a}}$ & $1.22^{\mathrm{a}}$ & $20.45^{\mathrm{a}}$ \\
Fanya juu & $37.44^{\mathrm{a}}$ & $36.00^{\mathrm{a}}$ & $26.11^{\mathrm{a}}$ & $1.17^{\mathrm{a}}$ & $19.15^{\mathrm{a}}$ \\
CV (\%) & 13.4 & 13.6 & 9.2 & 9.58 & 9.75 \\
P. Value & 0.03 & 0.09 & 0.41 & 0.23 & 0.38 \\
\hline
\end{tabular}

BD: Bulk density; CV: Coefficient of Variation; MC: Moisture Content.

Table 2. Mean value of physical soil properties as influenced by slope gradient.

\begin{tabular}{llllll}
\hline \multirow{2}{*}{ Slope gradient (\%) } & \multicolumn{5}{c}{ Parameters } \\
\cline { 2 - 6 } & Sand (\%) & Clay (\%) & Silt (\%) & BD $\left(\mathbf{g} / \mathbf{c m}^{\mathbf{3}}\right)$ & MC (\%) \\
\hline Gentle (5-10) & $29.22^{\mathrm{b}}$ & $44.88^{\mathrm{a}}$ & $25.00^{\mathrm{b}}$ & $1.22^{\mathrm{a}}$ & $20.53^{\mathrm{a}}$ \\
Middle (10-15) & $36.77^{\mathrm{a}}$ & $37.11^{\mathrm{b}}$ & $25.88^{\mathrm{ab}}$ & $1.26^{\mathrm{a}}$ & $18.98^{\mathrm{a}}$ \\
Steep (15-30) & $37.88^{\mathrm{a}}$ & $35.11^{\mathrm{b}}$ & $27.66^{\mathrm{a}}$ & $1.16^{\mathrm{a}}$ & $19.93^{\mathrm{a}}$ \\
CV (\%) & 13.4 & 13.6 & 9.2 & 9.58 & 9.75 \\
P. Value & 0.0069 & 0.0034 & 0.032 & 0.94 & 0.88 \\
\hline
\end{tabular}

BD: Bulk density; CV: Coefficient of Variation; MC: Moisture Content.

\subsection{Effect of Level Soil Bund and Fayna Juu on Selected Soil Chemical Properties a Long Slope Gradients}

Soil pH: The result showed that soil and water conservation practice was statistically affected soil $\mathrm{pH}$ $(\mathrm{P} \leq 0.05)$. The $\mathrm{pH}$ of the soils sampled from the treated and untreated plots of all the locations ranged from 4.76 to 5.99 . This could be categorized as strongly acid to moderately acid ranges according to [36]. The higher mean values of $\mathrm{pH}$ were recorded on farmland conserved with soil bunds (5.35) and fanya juu bunds (5.18) [Table 3]. The low $\mathrm{pH}$ reflected in the control plot might be related to high rainfall, associated with leaching and removal of important soil nutrients due to the absence of SWC structures. The result confirmed the finding of [31] who reported the mean $\mathrm{pH}$ at the control plot was lower than those of the treated plots (4.86) in Wonago district southern Ethiopia.

Along the slope gradient, no significant difference was observed in soil $\mathrm{pH}$, but the highest mean value (5.23) was found in the gentle slope compared with steep and middle slopes, which was (5.02) and (5.14), respectively [Table 4]. The lowest $\mathrm{pH}$ in soils of steep slope gradient could be attributed to the loss of basic cations through runoff erosion. This in turn increases the activity of $\mathrm{H}^{+}$ion in the soil solution and reduces soil $\mathrm{pH}$. In line with this result [37] also reported the highest $\mathrm{pH}$ (8.25) found at the bottom slope. Moreover; [38] reported that soil in steep slope had a significantly lower $\mathrm{pH}$ than those on another slope position due to the accumulation of soluble cations on the lower slope.

Soil organic carbon (SOC \%) showed significant variation with respect to treatment. The soil organic carbon content under the control plot $(1.18 \%)$ was significantly lower than farmland treated with soil bund $(1.78 \%)$ and fanya juu $(1.57 \%)$ structures. Trough, there was no significant variation observed between soil bund and fanya juu structures [Table 3]. This might due to SWC practice to reduce surface runoff, soil loss, and retain water that enhances crop growth and contributes to SOC input. It might also be related to higher biomass production in the conserved farmland. SOC did not show significant variation regarding slope gradient. However, the maximum mean value was observed at a gentle slope $(1.63 \%)$ and the minimum was at a steep slope $(1.36 \%)$ [Table 4]. This result was similar to [39] who reported that, the highest SOC content (1.04\%) for conserved microwatershed than that of non-conserved $(0.75 \%)$ in the Northwestern Highlands of Ethiopia. According to [40]; [35] and [38]; significant variation in SOC between treated and control sites was reported in different parts of Ethiopia.

Total nitrogen (TN \%) was showed a significant difference $(\mathrm{p} \leq 0.05)$ between conserved and non-conserved farmlands. However, there was no significant variation recorded between farmland treated with conservation structures [Table 3]. Reduced soil erosion and increased soil organic matter partly explain the higher $\mathrm{TN}$ in the conserved farmland. Likewise, [41] reported that farmland with physical SWC practices has high $\mathrm{TN}$ as compared to the non-conserved land. According to [42] the overall TN content in soils under control farm plots was significantly lower than the content under fanya juu of 5 and 10 years old. Furthermore, [43] reported variation in $\mathrm{TN}$ contents due to land uses and conservation difference in a Gojeb sub river basin of Dedo district, Southwest Ethiopia. The total nitrogen content did not show statistically significant variation with regard to slope gradients. However, the maximum mean value $(0.14)$ was observed at a gentle slope which was larger than that of steep slopes (0.11) [Table 4]. TN of all the slope gradients in the present study area was in the range of low to medium based on the rating suggested by [44].

Available phosphorous (Av. P ppm) was not shown significant variation under different treatments and slope gradients. With regard to swc practice, the maximum mean value $(1.83 \mathrm{ppm})$ was recorded for level soil bund and the minimum (1.51 ppm) was observed in the control plot. 
Likewise, the higher mean value (1.93 ppm) of available phosphorous was observed at a gentle slope and the minimum (1.27 ppm) was at a steep slope. The result of the analysis revealed that the available phosphorous for the study site was in a very low range. These were perhaps due to the difference in the past land degradation resulting from continuous cultivation and soil erosion, also it might be due to the fact that soil of the study area was within the acid range of 4.76 to 5.99 that the soil with a ph of less than 6 commonly has deficiencies of phosphorous. This study is in line with the findings of [45-47] who reported that most of the Ethiopian soils are deficient in available phosphorus concentration due to low $\mathrm{pH}$ (acidic), the intensive cropping system, imbalanced use of fertilizer, and nutrient mining. The result was in contrast with the finding of [38] who reported significant differences of available Phosphorus with regard to treatments and slopes.

Cation exchange capacity (CEC meq/100gm) was exhibited a significant $(\mathrm{p} \leq 0.05)$ difference between the treatments and slope gradients. The higher mean value of CEC was observed under level soil bund (26.69) and gentle slope (23.89) [Tables $3 \& 4$ ]. The soil of the study area was dominated by clay loam and Soils with a higher clay fraction tend to have a higher CEC. [38] reported that soil CEC demonstrated a significance difference with treatments and slope positions. The soil under the terraced farm plot showed higher CEC than non-terraced farmland. With regard to slope gradient, the highest mean value of CEC observed in the gentle slope might be attributed due to the accumulation of clay particles at the gentle slope through downward movement of fine particles along the slope because of erosion. Clay particle has the highest surface area. The result confirmed the findings of [48] who reported the highest CEC values for the gently sloping area.

Generally, the effect of SWC practices on soil properties was higher on soil bunds and gentle slope gradients in the entire study site. This is because of the most adopted and practiced types of conservation structures in the study area where soil bund compared to others. According to [49] the soil conservation measures adapted well to the local conditions and the local communities have protected the soil from being eroded and improve soil productivity. Steep slopes generally have shallow soils because soil that does develop regularly washed down the slopes into the gentle slope prior to the construction of SWC structures, due to this gentle slope gradient have nutrient deposition than a steep slope, when SWC practice was added the rate of nutrient regeneration was by far more rapid than that of a steep slope.

Table 3. Mean value of soil chemical properties as influenced by level soil bund and fayna juu.

\begin{tabular}{|c|c|c|c|c|c|}
\hline \multirow{2}{*}{ Treatments } & \multicolumn{5}{|c|}{ Parameters } \\
\hline & SOC (\%) & TN (\%) & AV. P (ppm) & CEC (meq/100gm) & $\mathrm{pH}\left(\mathrm{H}_{2} \mathrm{O}\right)$ \\
\hline Control & $1.18^{\mathrm{b}}$ & $0.101^{\mathrm{b}}$ & $1.51^{\mathrm{a}}$ & $23.73^{\mathrm{b}}$ & $4.86^{\mathrm{b}}$ \\
\hline Soil bund & $1.78^{\mathrm{a}}$ & $0.15^{\mathrm{a}}$ & $1.83^{\mathrm{a}}$ & $26.69^{\mathrm{a}}$ & $5.35^{\mathrm{a}}$ \\
\hline Fanya juu & $1.57^{\mathrm{a}}$ & $0.13^{\mathrm{a}}$ & $1.74^{\mathrm{a}}$ & $23.43^{\mathrm{b}}$ & $5.18^{\mathrm{a}}$ \\
\hline CV $(\%)$ & 19.27 & 19.24 & 22.6 & 10.83 & 4.24 \\
\hline P. Value & 0.0016 & 0.0015 & 0.55 & 0.03 & 0.0008 \\
\hline
\end{tabular}

Av. p: Available phosphorus; CEC: Cation Exchange Capacity; CV: Coefficient of Variation; pH: Soil reaction; SOC: Soil Organic Carbon; TN: Total Nitrogen.

Table 4. Mean value of soil chemical properties as influenced by slope gradients.

\begin{tabular}{lllll}
\hline Slope gradient (\%) & \multicolumn{3}{c}{ Parameters } \\
\hline & SOC (\%) & TN (\%) & AV. P (ppm) & CEC (meq/100gm) \\
\hline Gentle (5-10) & $1.63^{\mathrm{a}}$ & $0.14^{\mathrm{a}}$ & $1.93^{\mathrm{a}}$ & $27.15^{\mathrm{a}}$ \\
Middle (10-15) & $1.54^{\mathrm{a}}$ & $0.13^{\mathrm{a}}$ & $1.87^{\mathrm{a}}$ & $23.89^{\mathrm{b}}$ \\
Steep (15-30) & $1.36^{\mathrm{a}}$ & $0.11^{\mathrm{a}}$ & $1.27^{\mathrm{a}}$ & $22.82^{\mathrm{b}}$ \\
CV (\%) & 19.27 & 19.24 & 22.6 & 10.83 \\
P. Value & 0.17 & 0.17 & 0.08 & $5.14^{\mathrm{a}}$ \\
\hline
\end{tabular}

Av. p: Available phosphorus; CEC: Cation Exchange Capacity; CV: Coefficient of Variation; pH: Soil reaction; SOC: Soil Organic Carbon; TN: Total Nitrogen.

\subsection{Factors Affecting Farmers Adoption of Soil and Water Conservation Practices in the Study Area}

Basic household characteristics: The basic household characteristic refers to the general characteristics of the sample population, including a composition by age and sex, household size, education, and etc. The majority of the sample households (90\%) were male-headed households, while $10 \%$ of respondents were female-headed households [Table 5]. The dominance of male respondents revealed that they were dominant in the participation of SWC practices. The average age of sampled farmers was 40 with a minimum age of 20 and a maximum of 64 [Table 5]. Of the total respondents, $94.2 \%$ were married, 5.8 were singles. Out of the 120 households questioned, about $12.5 \%$ were not able to read and write, $18.3 \%$ had attended up to grade 4 , about $55 \%$ were attending their school up to grade 8 and the remaining $14.2 \%$ were attended their secondary school [Table 6]. Household family size and characteristics are directly related to the supply and demand conditions for basic human needs such as food, shelter, health, and educational facilities which in turn directly or indirectly influence the decision for soil and water conservation activities [50]. The average family sizes for the sampled household were 4 with the largest 
family size 15 and the smallest 2 [Table 5].

Table 5. Demographic and socioeconomic characteristics of households (HH).

\begin{tabular}{llllll}
\hline \multicolumn{5}{c}{ Descriptive Statistics } \\
\hline Variables & $\mathbf{N}$ & Minimum & Maximum & Mean & Std. Deviation \\
\hline Age & 120 & 20 & 64.00 & 40.66 & 9.89 \\
Education level of HH & 120 & 0 & 12.00 & 5.83 & 3.20 \\
HH Family size & 120 & 2 & 15 & 4.74 & 2.69 \\
Land size & 120 & 0.25 & 5.00 & 2.17 & 1.168 \\
Farm experience & 120 & 2.00 & 45.00 & 21.47 & 11.07 \\
Livestock holding & 120 & 0 & 37.00 & 4 & 4.76 \\
\hline
\end{tabular}

The overall mean the family size of 4 persons per household was the average family size of 4.9 persons per household [18]. This result disagrees with [51] who reported the average family size of 5.88 which is above average. Farm size and ownership are the two critical 'rural livelihoods issue for farmers of Ethiopia in general and the study area in particular. The landholding size of the respondents ranged from 0.25 to 5 ha with an average of about 2.17 ha. The majority of the respondents $(29.2 \%)$ however possessed 0.25 to 0.5 ha, only $5 \%$ of the respondents were possessed more than 1.5 ha of land. This result is similar to the finding of
[52] who reported that about $28 \%$ of the sample households have a farm size of 0.1-0.5 ha. However, [53] reported an average landholding size of 3.37 ha, which is by far larger than the 2007 national average of 0.85 ha. In addition to crop production, livestock rearing is the other major agricultural activity undertaken predominantly in the study area. Livestock is used for various purposes in the study area including plow power, milk, meat, eggs, transport and other purposes. The maximum livestock holding for the respondents were 37 and the minimum was 0 with an average livestock holding 4 per household [Table 5].

Table 6. Demographic characteristics of household (HHs).

\begin{tabular}{llll}
\hline Demographic description & & Frequency (N=120) & percent \\
\hline \multirow{2}{*}{ sex } & Male & 108 & 90 \\
& Female & 12 & 10 \\
Marital status & Married & 113 & 94.2 \\
& Single & 7 & 5.8 \\
& Not read and write & 15 & 12.5 \\
Education level & $1-4$ & 21 & 18.3 \\
& $5-8$ & 66 & 55 \\
\hline
\end{tabular}

\subsection{Farmers' Perception on Soil Erosion and Physical Soil and Water Conservation Practice}

Most of the respondents indicated that they perceived the soil erosion problems in their farmland [Table 7]. Regarding signs with which it can be identified, they rightly mentioned visible erosion features such as sheet, rills, gullies, and landslides. This is in agreement with [54] who reported the same results for Beressa watershed Ethiopia. [11], also reported $98.4 \%$ of the surveyed farmers recognized that soil erosion was a problem in their own farm. During focus group discussions, farmers also mentioned that even if the degree of erosion differs from plot to plot due to management practices and slope category they agreed on the occurrence of soil erosion on their farmlands. With regard to the causes of soil erosion, in their day-to-day activities, men have caused soil erosion problems. Their interaction with the natural environment resulted in the loss of precious topsoil that contains essential nutrients for plant growth, water holding capacity of the soil and ultimately leads to reduced crop yields [55]. Some farmers have a clear idea of why they have been facing erosion problems; whereas others only have general ideas rather than detailed causes of erosion. They asked to indicate the prominent causes for the problems and they mentioned free grazing (36.7\%), over-cultivation $(32.5 \%)$, cultivation of steep slopes (17.5\%), and deforestation (13.3\%) of the respondents. This result supports the findings of [17] who reports $36 \%$ of the sample farmers believed that free grazing was the most important cause of soil erosion. Free grazing got the larger valuable cause in the study area, livestock were fed $100 \%$ free on individual and communal land which might exacerbate the degree of soil erosion, this result was in contrast with the finding of [56] who reported poor agricultural practices as the leading causes of soil erosion at Kindo Didaye district, southern Ethiopia. However, most of the respondents considered that a combination of two or more factors was being used as the causes of soil erosion. 


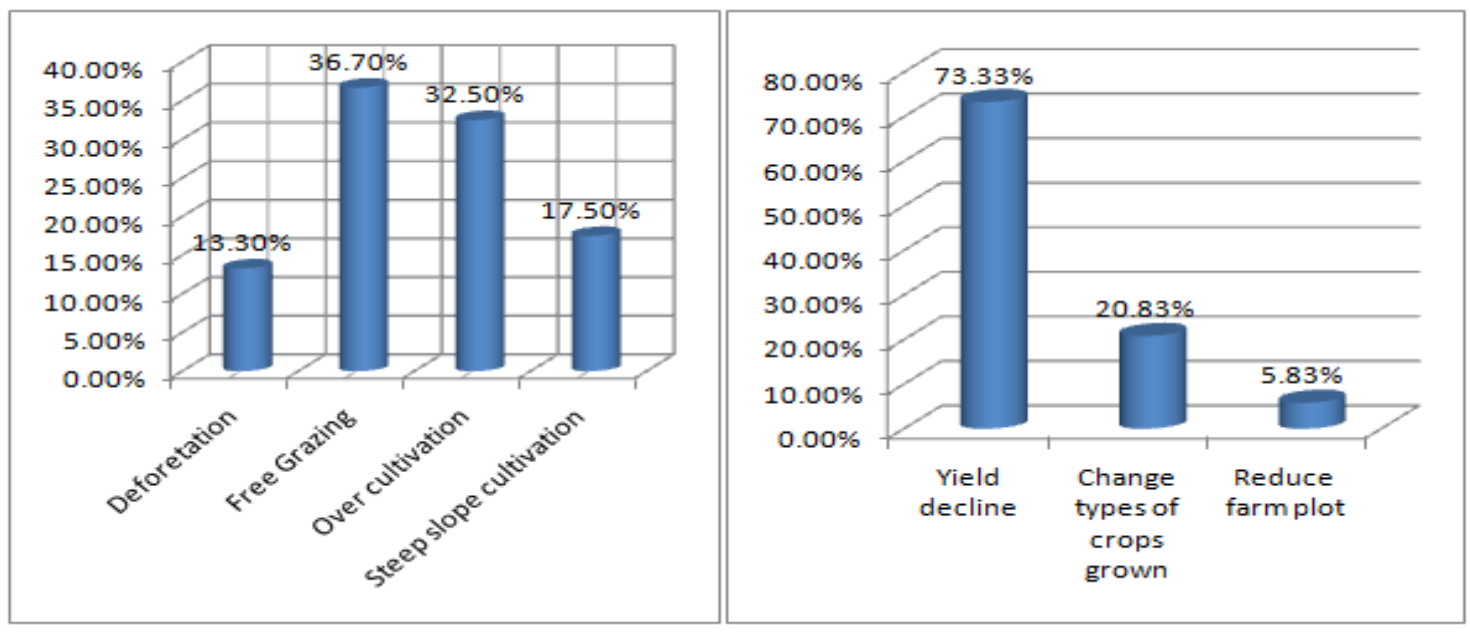

Figure 2. Farmers' response to causes and effects of soil erosion in the study area.

Farmers also asked for the severity of soil erosion in their farm plots and $76.7 \%$ of the respondents were answered as severe, $22.5 \%$ as medium, and only $0.8 \%$ of the household were perceived as low [Table 7]. The result supports the findings of [57], who reported as almost half of the farmer stated the extent of the problem as sever and some respondents mentioned that the rate of soil erosion has been increasing over the time while a small number of respondents believed that the extents of erosion were minor.

Table 7. Farmer's perception on soil erosion as a problem.

\begin{tabular}{llll}
\hline $\begin{array}{l}\text { Perception of farmer's } \\
\text { related to soil erosion }\end{array}$ & Option & Frequency & $\begin{array}{l}\text { Percentage } \\
\text { (N=120) }\end{array}$ \\
\hline $\begin{array}{l}\text { Is there soil erosion on your } \\
\text { farm plot }\end{array}$ & Yes & 120 & 100 \\
& No & 0 & \\
Severity of soil erosion & Severe & 92 & 76.7 \\
& medium & 27 & 22.5 \\
Severity over the past five & Low & 1 & 0.8 \\
years & Mevere & 9 & 7.5 \\
& No change & 37 & 61.7 \\
Can soil erosion be & Yes & 115 & 30.8 \\
controlled & No & 5 & 95.8 \\
\hline
\end{tabular}

Erosion reduces infiltration rates and water holding capacity of the soil, as well as the loss of plant nutrients which ultimately results in a reduction of productivity. Concerning the consequences of soil erosion, the opinion of the farmers on the impact of soil erosion on farm production was almost evenly divided between yield decline (73.33\%), change types of crops grown, $(20.83 \%)$ and reduces farm plots $(5.83 \%)$ [Figure 2$]$.

\subsection{Farmers' Participation in Physical Soil and Water Conservation Practices}

The participation of different actors at different phases of SWC practices enhances the possibility of achieving sustainable SWC outcomes. In the study area, almost all farmers agreed that SWC practice was very helpful for erosion control and better to improve soil productivity. The physical SWC practice, mainly soil bund and Fanya juu, has been practiced by integrating them with multipurpose biological measures such as vetiver grass. Soil bunds were constructed through community mass mobilization by technical support from development agents and woreda experts. Menschen fiir Menschen NGO was mainly focused on fanya juu. More than $95.8 \%$ of the respondents were agreed that they were participating in physical soil and water conservation practices during the last seven years and around $68.3 \%$ of the respondents were not actively participated in SWC practice this year as community mass mobilization. However, 7\% were constructed soil bund on their farm plots by the supports of DA's [Table 8]. Regular maintenance and management of the implemented SWC practice should be done for its sustainability in the area. However, field observation during the transect walk indicated that there weren't regular maintenance and management of conservation measures since implemented. The majority of respondents $(90.8 \%)$ agreed that there was no maintenance and management activity once the structures were constructed. The results agree with [58] that many farmers of the high potential area have not maintained physical soil and water conservation structures. But this finding is in contrast with [59], who reported the majority of the respondents $(56.57 \%)$ maintained soil and water conservation structures.

Table 8. Farmers 'participation in soil and water conservation measures.

\begin{tabular}{llll}
\hline Participation in SWC & Option & Frequency & Percent \\
\hline $\begin{array}{l}\text { Did you participate in SWC } \\
\text { practice during the last seven }\end{array}$ & Yes & 115 & 95.8 \\
years? & No & 5 & 4.2 \\
Did you participate in SWC & Yes & 38 & 31.7 \\
practice this year? & No & 82 & 68.3 \\
Did the structure maintained? & Yes & 11 & 9.2 \\
& No & 109 & 90.8 \\
\hline
\end{tabular}

\subsection{Adoption of Soil and Water Conservation Practice in the Study Area}

Farmers of the study area use different types of SWC structures, including soil bund, fanya juu, cut off drain, stone, 
and wooden check dams, planting different types of tree. About $48.3 \%$ of the interviewed farmers tried to implement conservation structures in their plots, while more than half, $51.7 \%$ were not tried any of the conservation practices on their farmland. From those constructed SWC structures are soil bund (34.5\%), fanya juu (24.1\%), stone bund (19.2\%), and the rest was $22.2 \%$ [Table 9]. The development agents and some farmers stated during the survey that Fanya juu was introduced in a few farmers 'land, but most of it failed or was broken shortly after construction, owing to the nature of the structure, and its liability for damage on steep land and the high rainfall area. Moreover, farmers were also asked to compare the problem of soil erosion in their farmlands after conservation structures were built; accordingly, the majority of them $(69.2 \%)$ confirmed that soil erosion rate had decreased after the implementation of different types of conservation structures. However, $0.8 \%$ and $30 \%$ of the respondents were perceived as aggravated and no change, respectively. More than half of the interviewed farmers $(67.5 \%)$ were agreed that implemented soil and water conservation structures had the potential to improve and productivity and increase yield. However, $31.7 \%$ of the respondents were never seen any change on their farm plots and $0.8 \%$ perceived as reduced yield [Table 9]. This result is generally supported by the finding of [59], who reported that soil and water conservation practices improved soil fertility of their farmland, increased water holding capacity of the soils, reduced runoff and erosion, and increased land productivity at Akusti micro watershed, northwest Ethiopia.

Table 9. Soil and water conservation practice in the study area.

\begin{tabular}{llll}
\hline $\begin{array}{l}\text { Soil and water conservation } \\
\text { practice }\end{array}$ & Option & Frequency & Percentage \\
\hline Did you practiced SWC & Yes & 58 & 48.3 \\
structures on your farm plot & No & 62 & 51.7 \\
& Soil bund & 41 & 34.5 \\
If yes for the above what are & Stone bund & 23 & 19.2 \\
their types? & Fanya juu & 29 & 24.1 \\
& Others & 27 & 22.2 \\
Problem of soil erosion after & Aggravated & 1 & 0.8 \\
SWC measures intervention & Reduced & 83 & 69.2 \\
& No change & 36 & 30 \\
Productivity after SWC & Increased & 81 & 67.5 \\
measures intervention & Reduced & 1 & 0.8 \\
& No change & 38 & 31.7 \\
\hline
\end{tabular}

\subsection{Problems of SWC Practices in the Study Area}

Although there had been great efforts in SWC practice in Africa, including Ethiopia, land degradation especially soil erosion is still escalating from time to time. This can be attributed to the inappropriateness of conservation practices, the inefficiency of experts, lack of awareness of farmers, land tenure relationships, and the like [55]. The focus group discussion result revealed that more than $85 \%$ of physical soil and water conservation was implemented starting from December 15. In another way December is the intensive harvesting season in the study area, Hence, the SWC measures implementation program was overlapped with the intensive harvesting seasons in the area. In this regard, all respondents complained about the timing of SWC measure implementation. During key informant interview, development agents confirmed that during planning, soil and water conservation intervention, a top-down approach was pursued where woreda office of agriculture and natural resources tell them what they are going to do and the opportunity for the farmers and DA's in participating at all level of the planning the intervention was rare.

Table 10. Household perception on problems of soil and water conservation structures.

\begin{tabular}{lll}
\hline \multirow{2}{*}{ Problems related to SWC } & \multicolumn{2}{l}{ Farmers response to the problem } \\
\cline { 2 - 3 } & Frequency & Percentage \\
\hline Reduce the size of farm land & 23 & 19.2 \\
Difficult to turn oxen & 31 & 25.8 \\
Labor intensive & 43 & 35.8 \\
Difficult to implement technically & 23 & 19.2 \\
\hline
\end{tabular}

Farmers in the study area asked to rank from the listed problems of physical SWC structures, including soil bund fanya juu and stone bund and they revealed as $35.8 \%$ laborintensive, $25.8 \%$ difficult to turn oxen, $19.2 \%$ difficult to implement technically and $19.2 \%$ said the structure reduces the size of their farm plot [Table 10]. This result is supported by [60], who reported as, from the interviewed farmers, the majority reported that some conservation measures like bund, cut off drain and waterways were difficult to tillage, need much labor, need incentives to implement, difficult to implement and reduce farm size.

\subsection{Factors Affecting the Adoption of Soil and Water Conservation Practices in the Study Area}

To identify the major factors that determine household heads to adopt SWC practice/whether soil and water conservation structures have existed on their farm plot, dependent variables were analyzed with 10 explanatory variables by using a binary logistic regression model. Here logistic regression was used because the dependent variables (adoption of SWC practice) are categorical, i.e. a value of 1 is given if the farmer was an adopter of SWC practice and or 0 for a non-adopter of the SWC practice Among the hypothesized explanatory variables, seven variables were found to significantly affect the adoption of SWC structures and the remaining was not significantly different.

Table 11. Adoption of soil and water conservation practice as affected by categorical variables.

\begin{tabular}{llllll}
\hline \multirow{2}{*}{ Variables } & \multicolumn{2}{l}{ Level of Adoption of SWC practices } & & & Total \\
\cline { 2 - 6 } & Adopter & & Non-adopter & N & N \\
\hline Sex of HH & $\mathbf{N}$ & $\mathbf{\%}$ & 53 & 85.48 & 108 \\
Male & 55 & 94.83 & 9 & 14.52 & 12 \\
Female & 3 & 5.17 & 90 & 10 & N \\
\hline
\end{tabular}




\begin{tabular}{|c|c|c|c|c|c|c|}
\hline \multirow{2}{*}{ Variables } & \multicolumn{6}{|c|}{ Level of Adoption of SWC practices } \\
\hline & \multicolumn{2}{|c|}{ Adopter } & \multicolumn{2}{|c|}{ Non-adopter } & \multirow{2}{*}{$\begin{array}{l}\text { Total } \\
120\end{array}$} & \multirow[b]{2}{*}{100} \\
\hline Total & 58 & 100 & 62 & 100 & & \\
\hline \multicolumn{7}{|c|}{ Marital status } \\
\hline Single & 2 & 3.45 & 5 & 8.1 & 7 & 5.8 \\
\hline Married & 56 & 96.55 & 57 & 91.9 & 113 & 94.2 \\
\hline Total & 58 & 100 & 62 & 100 & 120 & 100 \\
\hline \multicolumn{7}{|c|}{ Labor shortage } \\
\hline No & 34 & 58.62 & 13 & 20.97 & 47 & 39.17 \\
\hline Yes & 24 & 41.38 & 49 & 79.03 & 73 & 60.83 \\
\hline Total & 58 & 100 & 62 & 100 & 120 & 100 \\
\hline \multicolumn{7}{|l|}{ DA contact } \\
\hline Yes & 54 & 93.1 & 26 & 42 & 80 & 66.67 \\
\hline No & 4 & 6.9 & 36 & 58 & 40 & 33.33 \\
\hline Total & 58 & 100 & 62 & 100 & 120 & 100 \\
\hline
\end{tabular}

Table 12. Adoption of soil and water conservation practice as affected by continuous variables.

\begin{tabular}{lllllll}
\hline Level of Adoption of SWC practices & \multicolumn{1}{l}{ Total } \\
\hline \multirow{2}{*}{ Variables } & Adopters & & Non adopters & & \\
\cline { 2 - 7 } & Mean & S. D & Mean & S. D & Mean & S. D \\
\hline Age & 43.36 & 7.94 & 38.13 & 10.89 & 40.66 & 9.89 \\
Education level & 6.22 & 3.26 & 5.46 & 3.12 & 5.83 & 3.2 \\
Family size & 5.71 & 2.27 & 3.84 & 2.77 & 4.74 & 2.69 \\
Land size & 1.88 & 1.1 & 2.44 & 1.17 & 2.17 & 1.168 \\
Farm Exp. & 25.32 & 10.49 & 17.87 & 10.45 & 21.47 & 11.07 \\
Livestock holding & 5.3 & 5.83 & 3 & 3.14 & 4 & 4.76 \\
\hline
\end{tabular}

Table 13. Result of binary logistic regression model for factors influencing adoption of soil and water conservation practices.

\begin{tabular}{|c|c|c|c|c|c|c|}
\hline Explanatory variables & Estimated coefficient (B) & S. E. & Wald & Df & Sig. & Odd ratio $\operatorname{Exp}(B)$ \\
\hline Sex & $0.919^{\text {ns }}$ & 0.906 & 1.029 & 1 & 0.310 & 2.508 \\
\hline Age & $0.058^{* * *}$ & 0.020 & 7.913 & 1 & 0.005 & 1.059 \\
\hline Marital status & $1.857^{\mathrm{ns}}$ & 1.082 & 2.949 & 1 & 0.086 & 6.406 \\
\hline Education level & $0.259^{* *}$ & 0.112 & 5.349 & 1 & 0.021 & 1.295 \\
\hline Family size & $0.272^{* *}$ & 0.138 & 3.871 & 1 & 0.049 & 1.312 \\
\hline Landholding & $-0.502^{* *}$ & 0.223 & 5.054 & 1 & 0.025 & 0.605 \\
\hline Farm experience & $0.067^{* * *}$ & 0.019 & 12.543 & 1 & 0.000 & 1.069 \\
\hline Existence of labor shortage & $1.380^{* * *}$ & 0.530 & 6.785 & 1 & 0.009 & 3.976 \\
\hline Extension service/DA contact & $1.607^{* *}$ & 0.684 & 5.521 & 1 & 0.019 & 4.988 \\
\hline Live stockholding & $-0.122^{\mathrm{ns}}$ & 0.086 & 1.990 & 1 & 0.158 & 0.886 \\
\hline Constant & -7.375 & 2.560 & 8.298 & 1 & 0.004 & 0.001 \\
\hline
\end{tabular}

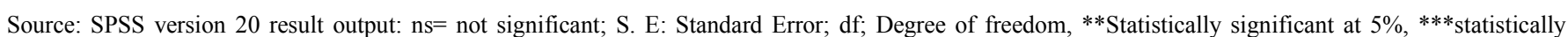
significant at $1 \%$.

\subsection{Demographic Factors and Adoption of SWC Practices}

Sex: The binary logistic regression result indicates that household heads sex had no impaction their adoption behavior of SWC technologies [Table 13]. This finding is similar to [50] who states that women have no significant difference with male-headed households in the adoption of SWC practices. [61] Also reported no significant relationship between household head sex and adoption of SWC measures. However significant relationships were reported by [62] that there was limited participation of women in the adoption of SWC practices and had limited access to information. They were highly involved in regular household activities than men.

Age: The age of the household head was highly significantly related to the adoption of SWC Practice in the study area [Table 13]. This may be due to the fact that older farmers were more aware of the problems of erosion and the importance of soil and water conservation practices. This result is similar to the finding of [17] who reported a unit increase in the age of $\mathrm{HH}$ head increases the adoption behavior of improved SWC structures by a factor of $0.35 \%$. However, [63, 64] reported as the age of a farmer increases, the acceptance level about the introduced soil and water conservation practices decreases.

Marital status: From those interviewed households, about $94.2 \%$ were married and the remaining $5.8 \%$ were single [Table 11]. The binary logistic regression result showed that there was no significant relationship between married and single household heads regarding the adoption of soil and water conservation technologies [Table 13]. This result was in line with [65] who reported that marital status of households did not show significant relation to the adoption of SWC practices in Karita Wuha watershed.

\subsection{Socio-economic Factors and Adoption of Soil and Water Conservation Practices}

Education level: education influences the farmers' decision 
to adopt technologies by enhancing the farmers' ability to obtain, understand, and utilize the practice, and by improving the overall managerial ability of farmers [65]. In this study, education was found to affect the adoption and continued use of soil and water conservation technologies positively at a 5\% significance level and increase the probability of use by a factor of 5.3 per additional year of education [Table13]. This implies that education may enable farmers to easily understand and recognize the problem of soil erosion, able to change, and put into practice the knowledge and skill they obtained from extension services and other sources. This result is in line with the finding of $[66,67]$, who reported that education enables farmers to tackle land degradation using various ways of soil conservation practices and it is significant at $95 \%$ of confidence level. However, [64] reported negatively and insignificant relationship between farmer's education level and adoption of soil and water conservation practice that as the educational level increases, the tendency to seek off-farm employment increases, while attention to the rural lifestyle decreases. [68] Confirmed that educated young farmers are more interested in jobs and business, rather than in taking up cultivation as an occupation.

Family Size: This is the number of household members living together. Physical conservation practices are laborintensive technologies. Studies conducted in Ethiopia indicated that, for the installation of recommended physical conservation measures, about 70 and 50 person-days per ha of soil and stone bunds, respectively, were estimated to be required [69]. As can be seen from [Table 13] household family size was positively affected by the adoption of SWC practices at a 5\% significance level. Different research findings have also supported this result, for instance [70] identified lack of interest in SWC practices to be a shortage of labor. [68] reported that large family size can provide more help in maintaining and repairing damaged SWC structures. But others mentioned that population growth has brought about land scarcity and land degradation [17], according to him large families do not spend their money on conservation practices; rather they spend it on food and other basic necessities.

Landholding size: Land size is negatively and significantly affects the adoption of SWC measures in the study area. As land size increase the adoption probability of conservation structure was decreased. This is because farmers with large farms have alternative land to plow, and can allow for a fallow period; hence, they may neglect the adoption and maintenance of SWC structures. This result is supported by the findings of [64] at Bokole watersheds southern Ethiopia. However, many researchers reported what was in contrast with this in different watersheds of Ethiopia. For instance, according to [71] landholding (Farm size) has positively influenced the adoption of SWC practices. Also [72] reported the adoption of SWC practice. The intention behind the proponents of this result was that a large farm size gives the farmer more flexibility in using various technologies than it is for farmers having small land size.

Existence of labor shortage: Labor, in addition to land and capital, is one of the ingredients for agricultural production. In the study area, farmers mainly depend on family labor for their farm activities and social purposes. The amount of labor available in a household is an important factor in the decision of the adoption of soil and water conservation practices [73]. In the study area, the average family size for adopters was 5 which were greater than that of non-adopters 3. This indicated that, families having small labor were less adopter. During focus group discussion farmers also revealed that labor was one of the major constraints to implement SWC as well as agricultural practices and hence daily labors were required at the peak agricultural period and implementing of physical SWC practices. Furthermore, according to [16] the high labor demand required for the implementation of SWC measures was found to be an important bottleneck in several case studies. This result is in contrast with the findings of [62] who reported no significant relationships between $\mathrm{HH}$ labor availability and adoption of SWC practices at the Meket Woreda northeastern Ethiopia.

Extension service: one of the widely used means of addressing information for the rural part of Ethiopia is public extension service. Development agents (DA) are responsible for disseminating the information for each kebeles to provide extension services [63]. Having good relation with DA's help farmers to be aware of improved SWC practices in reducing hazards associated with soil erosion [74]. In the study area, Extension support of SWC technologies had significant relations at $\mathrm{p} \leq 0.05$ as shown in [Table 13]. Having good relations with DA helps farmers in reducing hazards associated with soil erosion and conservation by providing information. Farmers who had access to extension support to SWC technologies like provision of seeds and seedlings and organizing farmers by teams adopted the improved SWC practices than those who did not have the access to the above supports. Focus group discussion with selected farmers also revealed that those farmers had the opportunity to see a good exercise in and outside the district adopted improved SWC practices than those who did not participate in the experience sharing or field day. The study indicated that if a farmer receives better information/advice from extension agents, the farmer will be willing to construct new conservation practices and to maintain the existing ones [69]. Generally, extension service is expected to influence farmers' adoption of improved soil and water conservation practices positively in the study area.

\section{Conclusion}

The result of the analysis showed that sand content (\%), SOC (\%), TN (\%), CEC (meq/100gm), and pH $\left(\mathrm{H}_{2} \mathrm{O}\right)$ were showed significant variation with SWC structures. However, silt content $(\%)$, clay content $(\%), \mathrm{BD}\left(\mathrm{g} \mathrm{cm}^{-3}\right), \mathrm{MC}(\%)$ and Av. P (ppm) were not shown significant differences with respect to soil and water conservation practice. Regarding the slope effects, soil textural fractions (sand, silt and clay contents) and CEC were significantly different along the slope gradients. However, BD, MC, SOC, TN, Av. P and $\mathrm{pH}$ 
did not show any variation with the slope gradients. Soil properties are relatively better on the conserved farm plots than on the non-conserved one. Soil bund and fanya juu structures had profound effect on some selected soil physicochemical properties of soil of the study area.

Concerning the adoption of soil and water conservation practice; Adopters and non-adopters socioeconomic and institutional variables; education level, family size, landholding, existence of labor shortage, age, farm experience, and extension service were significantly related to the adoption of soil and water conservation practices by the farmers. However, variables such as sex, marital status and livestock holding were not significantly related to conventional levels of probability.

In general, all soil properties were better at the soil bund therefore; it is better to scale up the practice to non-adopter's farmland. Woreda agricultural office and other concerning stakeholders shall be provided training and experience sharing programs at different levels to aware the farmers about the adverse effect of soil erosion and control mechanism. Participating farmers at different levels during soil and water conservation planning are essential to building a sense of ownership and creating continuous awareness to maintain the constructed structures to sustain its effect. Moreover, further investigation is encouraged on the integrated effect of physical and biological soil and water conservation practice and its socio-economic aspects for a better understanding of the effect for sustainable use of the land.

\section{Acknowledgements}

We would like to acknowledge the support of Dale Wabera district's agriculture and natural resource office for providing necessary information, different resources, and relevant data from the study site and department of natural resource and agricultural extension for their collaboration during field data collection. We are also thankful to the Nekemte soil research center and Jimma University, College of Agriculture and Veterinary medicine, Natural resource department, and laboratory technicians for their support during soil parameters analysis.

\section{References}

[1] J. De Graaff, A. Amsalu (2008) "Factors influencing adoption and continued use of long-term soil and water conservation measures in five developing countries. "Applied Geography 28 (4): 271-280.

[2] G. Temesgen, B. Amare (2014)"Land degradation in Ethiopia: causes, impacts and rehabilitation techniques. "Journal of environment and earth science 4 (9): 98-104.

[3] T. Gashaw (2015) Soil erosion in Ethiopia: Extent, conservation efforts and issues of sustainability.

[4] E. Yeshaneh, J. L. Salinas (2015) "Decadal trends of soil loss and run off in the Koga catchment, northwestern
Ethiopia."Land Degradation \& Development 28 (6): 18061819.

[5] B. Tefera and G. Sterk (2010) "Land management, erosion problems and soil and water conservation in Fincha'a watershed, western Ethiopia. "Land Use Policy 27 (4): $1027-$ 1037.

[6] B. Gessesse, W. Bewket (2015) "Model based characterization and monitoring of runoff and soil erosion in response to land use/land cover changes in the Modjo watershed, Ethiopia. "Land Degradation \& Development 26 (7): 711-724.

[7] J. Nyssen, M. Veyret-Picot (2004) "The effectiveness of loose rock check dams for gully control in Tigray, northern Ethiopia. "Soil Use and Management 20 (1): 55-64.

[8] K. R. Olson, M. Al-Kaisi (2016) "Impact of soil erosion on soil organic carbon stocks." Journal of soil and water conservation 71 (3): 61A-67A.

[9] B. Sundquist (2010) "Chapter9-Food supply from soil." Top soil Loss and Degradation - Causes, Effects and Implications.

[10] D. T. Meshesha, A. Tsunekawa (2012) "Dynamics and hot spots of soil erosion and management scenarios of the Central Rift Valley of Ethiopia. "International Journal of Sediment Research 27 (1): 84-99.

[11] W. Bewket (2007)" Soil and water conservation intervention with conventional technologies in north western highlands of Ethiopia: Acceptance and adoption by farmers." Land Use Policy 24 (2): 404-416.

[12] L. Desta, V. Carucci (2005)" Community- based participatory watershed development. a guide line.

[13] W. M. Mekuria, D. Chanie (2015)" Sustaining the benefits of soil and water conservation in the highlands of Ethiopia."

[14] Y. G. Selassie, F. Anemut (2015) "The effects of land use types, management practices and slope classes on selected soil physico-chemical properties in Zikr ewatershed, NorthWestern Ethiopia.' Environmental Systems Research 4 (1): 3.

[15] E. Kato, C. Ringler, M. Yesuf, E. Bryan 2011 Soil and water conservation technologies: a buffer against production risk in the face of climate change? Insights from the Nile basin in Ethiopia. Agricultural Economics, 42: 593-604.

[16] N. Haregeweyn, A. Tsunekawa (2015) "Soil erosion and conservation in Ethiopia: a review." Progressin Physical Geography 39 (6): 750-774.

[17] F. A. Mengstie (2009) Assessment of adoption behavior of soil and water conservation practices in the Koga watershed, highlands of Ethiopia, Cornell University.

[18] C. CSA (2007) The 2007 population and housing census of Ethiopia, CSA Addis Ababa.

[19] T. Gemtessa and K. Dera (2017)" Study on Prevalence of Bovine Trypanosomosisin Dale Wabera District, Kellam Wollega Zone, Western Ethiopia." Int J Anim Sci 1 (1): 1002.

[20] DWFEDO (2018) Dale Wabera Finance and Economic Development office annual report.

[21] R. Margesin, and F. Schinner (2005) Manual for soil analysismonitoring and assessing soil bio remediation, Springer Science \& Business Media. 
[22] R. Jahn, H. Blume (2006) Guide lines for soil description, FAO.

[23] C. A. Black, D. D. Evans, RC. Dinauer 1965 Methods of soil analysis. Madison, WI: American Society of Agronomy USA. 9: 653-708.

[24] G. R. Blake and Hartge K. H. 1986 Bulk density1. Methods of soil analysis: part1-physical and mineralogical methods, (methods of soilan1), pp. 363-375.

[25] E. Van Ranst, M. Verloo, etal. (1999) Manual for the soil chemistry and fertility laboratory: analytical methods for soils and plants equipment, and management of consumables.

[26] J. Z. Kjeldahl (1992) A new method for the determination of nitrogen in organic bodies analytical chemistry. pp. 22: 366 .

[27] Van Reeuwijk, (2002) Procedures for soil analysis, international soil reference and information centre, $6700 \mathrm{AJ}$ Wageningen the Netherlands.

[28] R. H. Bray and L. Kurtz (1945) "Determination of total, organic, and available forms of phosphorus in soils. "Soil science 59 (1): 39-46.

[29] W. G. Cochran (1977) Sampling techniques (3rded.). New York: John Wiley \& Sons.

[30] W. Hailu (2017) "Impact of Physical Soil and Water Conservation Structure on Selected Soil Physico chemical Properties in Gondar Zuriya Woreda. "Resources and Environment 7 (2): 40-48.

[31] Y. T. Ademe and Kebede (2017) "Evaluation of the effectiveness of soil and water conservation practices on improving selected soil properties in Wonago district, Southern Ethiopia. "Journal of Soil Science and Environmental Management 8 (3): 70-79.

[32] J. Tugizimana (2015) Effects of soil and water conservation techniques on soil productivity and bean grain yield in Nyamasheke District, Rwanda, Doctoral Dissertation, School of Agriculture and Enterprise Development.

[33] B. Bahilu, L. Mulugeta et al. (2014) "Soil fertility status as affected by different land use types and to pographic positions: a case of Deltasub-watershed, South western Ethiopia. "Journal of Biology, Agriculture and Health care 4 (27): 91105.

[34] Z. M. Easton and A. M. Petrovic (2005) "Effect of hill slope on nutrient run offf romturf. "Golf Course Manage 2005: 109113.

[35] A. A. Challa and Abdelkadir (2016) "Effects of graded stone bunds on selected soil properties in the central high lands of Ethiopia." International Journal of Natural Resource Ecology and Management 1 (2): 42-50.

[36] USDA Natural Resources Conservation Service. 1998.

[37] F. Khan, Z. Hayat (2013) "Effect of slope position on physico-chemical properties of eroded soil." Soil Environ 32 (1): $22-28$.

[38] D. Taressa 2017 "The Effectiveness of Stone Bund to Maintain Soil Physical and Chemical Properties: The Case of Weday Watershed, East Hararge Zone, Oromia, Ethiopia."

[39] Z. Siraw, and W. Bewket (2018) "Effects of CommunityBased Watershed Development on Soi Properties in the North western High lands of Ethiopia." Malaysian Journal of Soil Science 22: 19-33.

[40] T. Amare, A. Terefe (2013). "Soil properties and crop yields a long the terraces and toposequece of Anjeni Watershed, Central High lands of Ethiopia. "Journal of Agricultural Science 5 (2): 134.

[41] M. Demelash, and K. Stahr (2010) "Assessment of integrated soil and water conservation measures on key soil properties in South Gonder, North-Western High lands of Ethiopia." Journal of Soil Science and Environmental Management 1 (7): 164-176.

[42] W. Hailu, A. Moges (2012) "The effects of 'fanya juu' soil conservation structure on selected soil physical \& chemical properties: the case of Goromti watershed, western Ethiopia." Resources and Environment 2 (4): 132-140.

[43] B. Bezabih, A. Aticho (2016) "The effect of land management practices on soil physical and chemical properties in Gojeb Sub-river Basin of Dedo District, Southwest Ethiopia." Journal of Soil Science and Environmental Management 7 (10): 154-165.

[44] T. Tadesse, I. Haque, (1991)."Soil, plant, water, fertilizer, animal manure and compost analysis manual."

[45] L. Alemu, M. Tekalign, H. Wassie and Sh. Hailu (2016) Assessment and Mapping of Status and Spatial Distribution of Soil Macronutrients in Kambata Tembaro Zone, Southern Ethiopia. Advances in Plants and Agriculture Research, 4 (4): 144.

[46] L. Fanuel, K. Kibebew, M. Tekalign and G. Heluf 2016 a Soil-Plant Nutrient Status and their Relations in MaizeGrowing Fields of Wolaita Zone, Southern Ethiopia. Communications in Soil Science and Plant Analysis, 47 (11): 1343-1356.

[47] J. Kehali, M. Tekalign and K. Kibebew 2017 Characteristics of agricultural landscape features and local soil fertility management practices in Northwestern Amhara, Ethiopia. Journal of Agronomy, 16 (4): 180-195.

[48] M. Aytenew (2015) "Effect of slope gradient on selected soil physicochemical properties of Dawja watershed in Enebse Sar Midir District, Amhara National Regional State. "Am. J. Sci. Industr. Res 6 (4): 74-81.

[49] M. Getnet and S. Quraishi (2014) Effect of soil conservation measures on some physico-chemical properties of soil and crop yield in simada district, south gondar zone, Ethiopia, Haramaya University.

[50] A. Fikru (2009) "Assessment of Adoption Behaviour of Soil and Water Conservation Practices in the Koga Watershed, High lands of Ethiopia." MPS Thesis. Cornell University, United States: 62.

[51] M. T. Atsbaha and R. Reddy (2014) Farmers' Perception of Soil Erosion and Adoption of Soil Conservation Measures in Kolla Tembien Tabia Awotbkalsi, Tigray Regional State, Ethiopia, Haramaya University.

[52] S. Tamiru, A. Katiso and M. Mengesham (2018) Adoption of Physical Soil and Water Conservation Measures and Their Effect on Selected Soil Properties in Chingo Watershed, Southern SNNPR Ethiopia (Doctoral dissertation, Haramaya University). 
[53] M. D. Alemu, A. Kebede and A. Moges (2019) Farmers' Perception of Soil Erosion and Adoption of Soil Conservation Technologies at Geshy Sub-Catchment, Gojeb River Catchment, Ethiopia. Agricultural Sciences, 10, 46-65.

[54] T. W. Meshesha and S. K. Tripathi (2016) "Farmer's perception on soil erosion and land degradation problems and management practices in the Beressa Watershed of Ethiopia." Journal of Water Resources and Ocean Science 5 (5): 64-72.

[55] E. Kediro (2015) Farmers Perception on Soil Erosion and Effect of Conservation Structures on Soil Properties and Wheat Yield in Fulaso Watershed Sebeta Oromia, Addis Ababa University.

[56] M. Merkineh Mena (2018) Community Adoption of Watershed Management Practices at Kindo Didaye District, Southern Ethiopia. International journal of environmental science and natural resources Volume 14 issue 3.

[57] G. W Zerssa, B. Bezabih (2017) "Assessment of farmers perception towards soil and water conservation in Obi Koji Peasant Association, Woliso District, SouthWest Shewa Ethiopia. "Journal of Ecology and The Natural Environment 9 (3): 45-52.

[58] A. Mekuriaw, A. Heinimann (2018) "Factors influencing the adoption of physical soil and water conservation practices in the Ethiopian highlands. "International Soil and Water Conservation Research 6 (1): 23-30.

[59] D. T. Meshesha, G. Fisseha (2018) "Effects of Soil and Water Conservation Practices on Selected Bio-physical, and Livelihood Attributes and Farmers Perception at Akusti Micro Watershed, Northwest Ethiopia. "Journal of Agriculture and Environmental Sciences 3 (2): 57-75.

[60] D. Simeneh and F. Getachew (2015) "Perception of Farmers towards Physical Soil and Water Conservation Structures in Wyebla Watershed, Northwest Ethiopia. "Academic Journal of Plant Sciences 7 (3): 34-40.

[61] B. S. Demissie (2009) Factors affecting the adoption of soil and water conservation practices in northeastern Ethiopia (M. A) thesis) Addis Ababa University.

[62] S. Birhanu (2016) Assessment of factors determine farmers adoption behavior of soil and water conservation practice: Libo Kemkem Woreda, MA Thesis, Addis Ababa University, Ethiopia.

[63] K. Wolka and M. Negash (2014) "Farmers' adoption of soil and water conservation technology: acase study of the Boko leand Tonisub-watersheds, southern Ethiopia. "Journal of Science \& Development 2 (1): 35-48.

[64] D. Asfaw and M. Neka 2017 Factors affecting adoption of soil and water conservation practices: the case of Wereillu Woreda (District), South Wollo Zone, Amhara Region, Ethiopia. International Soil and Water Conservation Research, 5 (4): 273-279.

[65] A. Mulie (2012) Adoption of Soil and Water Conservation Practices on Farmlands: The Case of Karita Wuha Watershed, West Belessa District, North Gondar, Ethiopia, ST. Mary's University.

[66] L. M. Long (2003) Conservation practices adoption by agricultural land owners, Northern Illinois University.

[67] S. Tedla (2003) "Ethiopians Environmental Condition: Today and Twenty five Years from Now In Economics focus." Bullet in of Ethiopian Economics Association 5 (5).

[68] G. Bagdi (2005) People's participation in soil and water conservation through watershed approach, International Book Distributing Co.

[69] W. Bekele and L. Drake (2003) "Soil and water conservation decision behavior of subsistence farmers in the Eastern Highlands of Ethiopia: a case study of the Hunde-Lafto area. "Ecological economics 46 (3): 437-451.

[70] W. Bewket (2003) Land degradation and farmers' acceptance and adoption of conservation technologies in the Digil Watershed, Northwestern Highlands of Ethiopia, OSSREA.

[71] R. Reddy and M. Melese (2016) Adoption of Soil and Water Conservation Practices among smallholder farmers: The case of Boloso Sore Woreda, Wolaita Zone, SNNPR, Ethiopia, Haramaya University.

[72] R. B. Seenga (2014). Factors influencing adoption of soil conservation measures sustainability and socio-economic impacts among smallholders farmers in Mbeya rural district, Tanzania, Sokoine University of Agriculture.

[73] M. Erkie (2016) Asessment of Farmers' Awareness and Adoption on Soil and Water Conservation Practices: The Case of Borebor Micro watershed, Dera Woreda, Ethiopia, Addis Ababa University Addis Ababa.

[74] F. Beyene and A. Temesgen (2014) Perception of Smallholder Farmers towards Adoption of Improved Soil and Water Conservation Practices in Lemo Woreda, Hadiya Zone, Snnpr, Haramaya University. 